\title{
Indeks Kepuasan Mahasiswa pada Sarana Prasarana Kuliah di Fakultas Keguruan dan IImu Pendidikan Universitas Lambung Mangkurat
}

\author{
Lusiana Febrianti, Suratno, Maulana Rizky \\ Universitas Lambung Mangkurat, Banjarmasin, Indonesia \\ lusianafebrianti19@gmail.com
}

\begin{abstract}
The purpose of this study was to measure how the level of students' satisfaction of using college infrastructure. that includes the types of services: (I) Furniture, (2) Equipment, and (3) Media. The research method used quantitative descriptive, the research sample was taken with random sampling technique. the research subject was consisted of 467 students from the batch of 2016 and 2018. The data collection technique was used a questionnaire that had fulfilled the validity test with the KMO responsivness was 0.721 , assurance was 0.694 , tangibles was 0.765 , the empathy was 0.806 and the reliabillty was 0.835. The questionnaire was declared reliable with a value of responsiveness was 0.905, assurance was 0.898, tangibles was 0.903, empathy was 0.938 and reliability was 0.94I. Data analysis was used descriptive analysis and hypothesis testing. Hypothesis test result show that the dimension of responsiveness of satisfaction level was influenced by aspects of furniture, equipment, and media together with RyII.I2.I3 $=0.800 p$ $<0.01$, for the assurance dimension with $R_{y} 21.22 .23=0.804 p<0.01$, for the tangibles dimension with $R_{y} 31.32 .33=$ $0.820 p<0.01$, for empathy dimensions with $R_{y} 41.42 .43=0.803 p<0.01$ and for reliabillty dimensions with $R_{y} 51.52 .53=0.747 p<0.01$.
\end{abstract}

Keywords: Satisfaction Index and Infrastructure Facilities

\begin{abstract}
Abstrak
Tujuan penelitian ini mengukur bagaimana tingkat kepuasan mahasiswa terhadap pemanfaatn sarana prasarana kuliah yang meliputi jenis layanan : (I) Perabotan, (2) Peralatan, dan (3) Media. Metode penelitian menggunakan deskriptif kuantitatif, sampel penelitian diambil dengan teknik random sampling subjek penelitian terdiri 467 mahasiswa dari angkatan 2016 dan 2018. Teknik pengumpulan data menggunakan kuesioner yang telah memenuhi uji validitas dengan niai $\mathrm{KMO}$ responsivness $0,72 \mathrm{I}$, assurance 0,694 , tangibles 0,765 , empathy 0,806 dan reliabillty 0,835 . Kuesioner dinyatakan reliabel dengan nilai responsivness 0,905 , assurance 0,898 , tangibles 0,903 , empathy 0,938 dan reliabillty 0,94I. Analisis data menggunakan analisis deskriptif dilanjutkan dengan uji hipotesis. Hasil uji hipotesisi menunjukkan pada dimensi responsiveness tingkat kepuasan dipengaruhi oleh aspek perabotan, peralatan, dan media secara bersama dengan Ry11.12.13 $=0,800 \mathrm{p}<0,0 \mathrm{I}$, untuk dimensi assurancedengan $\mathrm{R}_{21.22 .23}=0,804 \mathrm{p}<0,0 \mathrm{I}$, untuk dimensi tangibles dengan Ry31.32.33 $=0,820 \mathrm{p}<0,0 \mathrm{I}$, untuk dimensi empathy dengan Ry41.42.43 $=0,803 \mathrm{p}<0,0 \mathrm{I}$ dan untuk dimensi reliabillty dengan Rys1.52.53 $=0,747 \mathrm{p}<0,0 \mathrm{I}$.
\end{abstract}

Kata Kunci : Indeks Kepuasan dan Sarana Prasarana 


\section{Pendahuluan}

Seiring berkembangnya teknologi yang diiringi juga dengan persaingan untuk menjadi yang terbaik memiliki pengaruh yang besar pada tingkat universitas untuk sekurang-kurangnyaharus melengkapi syarat pendidikan nasional yang memiliki 8 standar yaitu syaratlulusan kompetensi, syarat inti sebuah pembelajaran, syarat langkah-langkahsebuah pembelajaran, syarat penilaian pembelajaran, syarat tenaga pendidik (dosen), syarat sarana dan prasarana dari pembelajaran, syarat pengurusan proses belajar dan standar pendanaan proses belajar. Mahasiswa sebagai konsumen jasa dalam Perguruan Tinggi tentunya untuk memilih melanjutkan pendidikan yang lebih tinggi di suatu Perguruan Negri atau swasta salah satu alasan yang menarik minat adalah sarana dan prasarana yang dipunyai oleh Perguruan Tinggi. Ketersediaanya sarana dan prasarana yang maksimal akan berpengaruhpada proses pembelajaran yang diharapkan lebih efektif dan efesien. Standar Nasional Pendidikan Tinggi dalam aturan Mentri Riset, Teknologi, dan Pendidikan Tinggi No 442015 Pasal 3 I kualifikasi minimal syarat sarana \& prasarana sesuai keperluaanproses dan isi pembelajaran dalam upaya pencapaian pembelajaran. Dari ketetapan pemerintah t maka semua universitas yang ada di Indonesia harus mengikuti peraturan pemerinta.

Fakultas Keguruan dan Ilmu Pendidikan (FKIP) yakni fakultas termasuk yang memiliki mahasiswa terbanyak, setiap tahunnya lebih dari seribu mahasiswa yang diterima di FKIP di 2I program studi. Jumlah mahasiswa yang lebih dari seribu membuat pengelolaan dari jurusan atau program studi masing-masing harus mengatur jadwal kuliah, pembagian ruang sesuai program studi, jadi ketika kuliah sudah menempati ruangan kuliah masing-masing. Tetapi dalam hal ini, ada saja hal yang terjadi seperti kurangnya ruang untuk kuliah, jumlah mahasiswa yang banyak tidak diiringi dengan jumlah kursi dan banyak kursi yang sudah tidak layak pakai, kecilnya ruang beribadah atau musala sehingga tidak bisa terlalu banyak menampung mahasiswa yang mau beribadah, alat bantu proyektor yang kadang-kadang terlalu lama dipakai menjadi eror, jumlah pengeras suara yang tidak disesuaikan dengan jumlah ruang kuliah, ketersedian rujukan buku dengan tahun terbaru sedikit, prasarana lahan parkir yang sempit dan belum tertata dengan baik, dan hal yang sangat penting lagi dalam menunjang proses pembelajaran seperti wi-fi yang disediakan masih terbatas dengan kecepatan akses internet masih lambat padahal untuk keperluan akademik atau administrasi mahasiswa yang dilakukan secara online apalagi sekarang sebagian dosen yang pembelajarannya berbasis E-learning.

Menurut Yama \& Setiani (2016) sarana dan prasarana pendidikan merupakan semua benda yang bergerak atau tidak bergerak, yang digunakandalam saat pengajaran berlangsung. Semua satuan sebuah pendidikan wajib mempunyai sarana mencakup peralatan pendidikan, perabotan pendidikan, dan media pendidikan serta sumber belajar lainny yang dibutuhkan dalam membantu prosedur belajar mengajar yang beraturan \& berlanjut, Prastyawan (2016). Semua bahan, perlatan, perabotan ketika digunakan saat pengajaran disekolah untuk prasarana pendidikan yakni kelengkapan dasar sauatu perangkat yang digunakan saatpengajaran di sekolah, Megasari (20I4), adapun Sari (20I5) berpendapat bahwa prasarana dikategorikan ada 2 macam yakni, prasarana secara langsung dan prasarana secara tidak langsung, prasarana secara langsung yaknidipergunakan saat pengajaran dalam membantu pembelajran di dalam kelas ataupun diluar ruang kelas sedangkan prasarana secara tidak langsung yakni tidak dipergunakan pada saat pengajaran, contoh ruang guru, ruang pimpinan, tempat beribadah/mushalla , tata usaha, gudang, tempat bermain dan olahraga serta lahan parkiran motor.Sarana dan prasarana yang adalah bagian penting akan penerapan tri dharma pada universitas, meliputi tempat bangunan, peralatan yang digunakan langsung mauppun tidak langsung, dan perabotan saat pengajaran berlangsung,Sawitry (2015), sedangkanmenurutFauzan (2018) sarana dan prasarana yang ada pada pendidikan ialah bagian dari sumber daya utama dan juga sebgai gambaran akan kemajuan pada suatu lembaga pendidikan untuk memberikan motivasi penuh pada pengajaran.Perguruan Tinggi yang baik ialah perguruan yang mencukupi kebutuhan mahasiswa saat pembelajaran baiik itu dari segi sarana \& prasarana., tidak dapat dipungkiri taraf pendidikan dilengkapi sarana $\&$ prasarana sesuai dengan standar nasional tingkat universitas, untuk mengukur suatu keberhasilan di Perguruan Tinggi maka bisa dilihat dari puas atau tidak 
puasnya mahasiswa sebagai konsumen jasa pendidikan di suatu Perguruan Tinggi. Keberhasilan dalam pengukuran tingkat pelayanan menggunakan lima dimensi yaitu: tangibles, responsiveness, reliability, empathy, dan assurance, Lestari \& Yusmino (2018).

Mahasiswa pernah merasakan bagian tingkat kepuasan secara umum yakni, kemampuan di bawah kehendak lalu mengakibatkan mahasiswa merasa tidak puas, kemampuan sebanding dengan kehendak yang akan mengakibatkan mahasiswa merasa puas, kemampuan melebihi kehendak yang nantinya mengakibatkan mahasiswa merasa sangat puas. Perasaan tidak memuaskan, memuaskan dan sangat memuaskan tentu mempengaruhi respons selanjutnya, Bhakti \& Rahmawati (2017).Kepuasan ialah perasaan yang muncul baik itu bahagia/kecewa ketika hasil yang diharapkan dimana keinginaan terpenuhi akan harapan dan kebutuhan mahasiswa. Apabila yang diberikan memenhi harapan dinilai sebagai pelyanan memuasakan, sebaliknya jika tidak terpenuhinya harapan maka dinilai pelayanan idak memuaskan, Alliyah \& Sunarti (2017).Adapun pengertian lain dari Kepuasan mahasiswa yaitu evaluasi emosional dari pengalaman yang berhubungan dengan pendidikan yang diperoleh setelah membandingkan dengan harapan Martasubrata \& Suwanto (2016). Sedangkan menurut Irawan \& Komara (2017) kepuasan merupakan tindakan yang dilakukan konsumen dengan menilai kemampuan dengan kehendak. Ketika hasil yang dirasakan dibawah kehendak, maka konsumen merasa kurang puas, tidak puas atau kecewa dan sebaliknya.Upaya memuaskan pelanggan/konsumen sangat sulit dikarenakan kompetisi yang ketat dan lingkungan sosial juga berpengaruh pada prilaku pelanggan yang diiringi perkembangan ekonomi yang semakin luas.

Keberhasilan pada strategi pendidikan pada proses pembelajaran dipengaruhi beberapa faktor yakni, peserta didik, tenaga kependidikan, kurikulum, dana, sarana \& prasarana serta faktor lingkungan lain. Ketika faktor tersebut dapat dipenuhi dengan sebaik mungkin maka dapat membentuk peningkatan mutu pendidikan di Indonesia, Lestari \& Yusmino (2018)

\section{Metode}

Penelitian menggunakan pendekatankuantitatif dengan analisis deskriptif korelasi. Pengambilan sampel menggunakanteknikrandom sampling, denganjumlahsampel467 orang mahasiswa FKIP ULM yang terdiri dari angkatan 2016 dan 2018.Pengumpulan data menggunakan kuesioner yang telah diuji dengan menggunakan uji KMO dan Barlett's Test.Instrumen pada penelitian ini dinyatakan reliabel, dengan hasil reliabilitas sarana prasarana pada aspek responsivenesssenilai 0,9I, untuk sarana prasarana pada aspek assurance senilai 0,89, untuk sarana prasarana pada aspek tangibles senilai 0,90, untuk sarana prasarana pada aspek empathy senilai 0,94, untuk sarana prasarana pada aspek reliabillity senilai 0,94.

Analisis data menggunakan statistik deskriptif persentase, dilanjutkananalisisuntuk mengetahui pengaruh dari sarana prasarana yang meliputi perabotan, peralatan dan media terhadap responsiveness, assurance, tangibles, empathy dan reliabillty serta mengetahui kekuatan hubungan dari masing-masing variabel digunakan analisis regresiganda, dan korelasi parsial.

\section{Hasil dan Pembahasan}

Gambaran tentang Indeks Kepuasan Mahasiswa Pada Sarana Prasarana Kuliah di Fakultas Keguruan dan Ilmu Pendidikan Universitas Lambung pada grafik dibawah ini: 

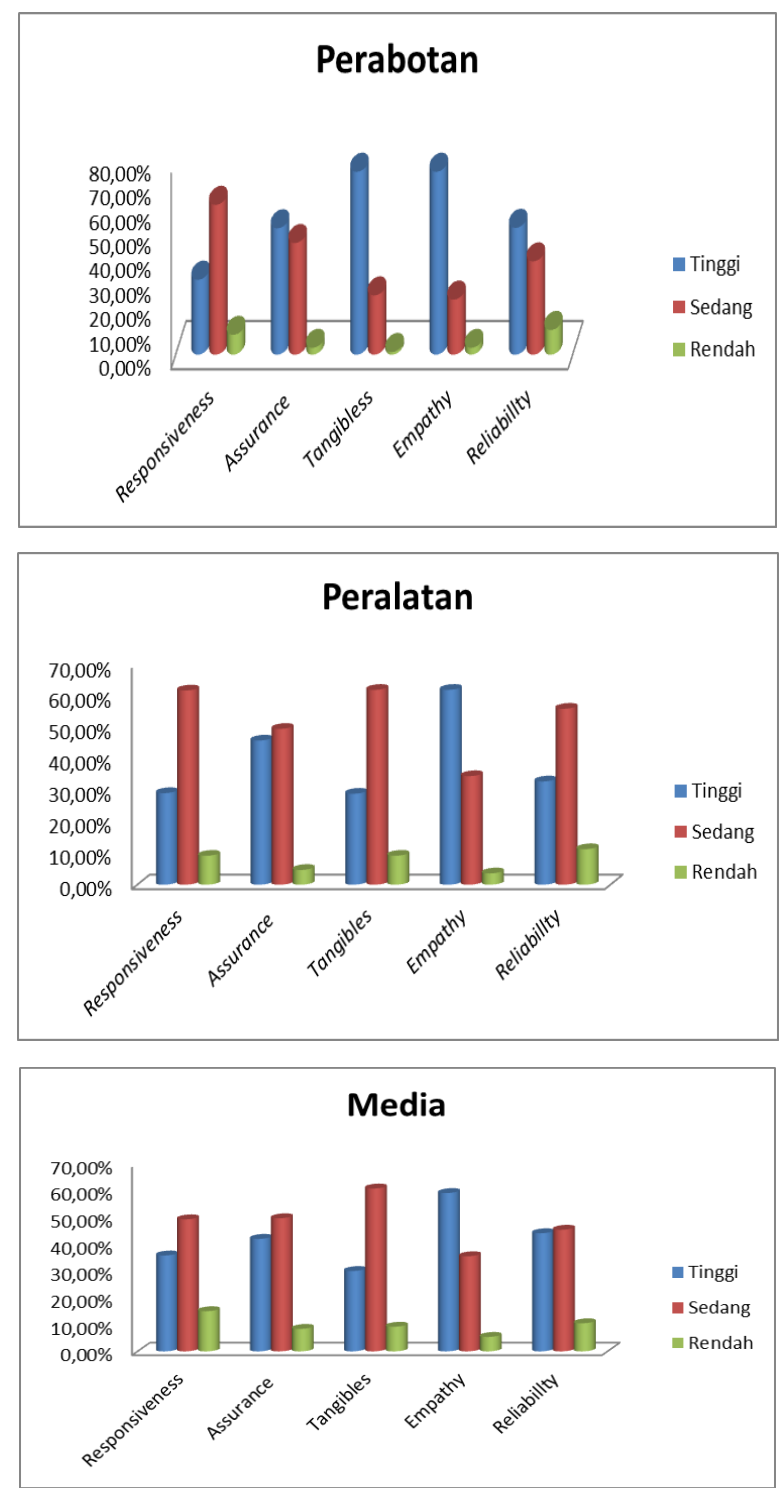

Grafik I. Indeks Kepuasan Mahasiswa Pada Sarana Prasarana Kuliah di Fakultas Keguruan dan Ilmu Pendidikan Universitas Lambung Mangkurat

Berdasarkan isi grafik tersebut dapatdisimak, bahwa indeks kepuasan mahasiswa untuk dimensi responsivness untuk aspek perabotan yang termasuk dalam kategori tinggi terdapat I43 mahasiswa atau 30,6\%, kemudian yang termasuk dalam kategori sedang terdapat 286 mahasiswa atau 61,2\%, kemudian yang termasuk dalam kategori rendah terdapat 38 mahasiswa atau 8,I\%, untuk dimensi assurance yang termasuk dalam kategori tinggi terdapat 24I mahasiswa atau 5I,6\%\%, kemudian yang termasuk dalam kategori sedang terdapat $2 \mathrm{I} 3$ mahasiswa atau 45,6\%, kemudian yang termasuk dalam kategori rendah terdapat I3 mahasiswa atau 2,8\%, untuk dimensi tangibles,yang termasuk dalam kategori tinggi terdapat 349 mahasiswa atau 74,7\%, kemudian yang termasuk dalam kategori sedang terdapat II3 mahasiswa atau 24,2\%, kemudian yang termasuk dalam kategori rendah terdapat 5 mahasiswa atau I,I\%, dan untuk dimensi empathy, yang termasuk dalam kategori tinggi terdapat 349 mahasiswa atau 74,7\%, kemudian yang termasuk dalam kategori sedang terdapat I05 mahasiswa atau 22,5\%, kemudian yang termasuk dalam kategori rendah terdapat I3 mahasiswa atau 2,8\%. Selanjutnya untuk dimensi reliabilltyindeks kepuasan mahasiswa yang termasuk dalam kategori tinggi terdapat 242 mahasiswa atau 5I,8\%, kemudian yang termasuk dalam kategori sedang terdapat 178 mahasiswa atau 38,1\%, kemudian yang termasuk dalam kategori rendah terdapat 47 mahasiswa atau I0,1\%. 
Setelah menyimakdeskripsitentang gambaranindekskepuasan mahasiswa untuk aspek perabotan, berikutdidiskripsikan gambaran indekskepuasan mahasiswa untuk aspek peralatan. Kepuasan mahasiswa untuk dimensi responsivness untuk aspek peralatan yang termasuk dalam kategori tinggi terdapat I36 mahasiswa atau 19,1\%, kemudian yang termasuk dalam kategori sedang terdapat 288 mahasiswa atau 6I,7\%, kemudian yang termasuk dalam kategori rendah terdapat 43 mahasiswa atau 9,2\%, untukindeks kepuasan mahasiswa pada dimensi assurance, yang termasuk dalam kategori tinggi terdapat 2I4 mahasiswa atau 45,8\%, kemudian yang termasuk dalam kategori sedang terdapat 23I mahasiswa atau 49,5\%, kemudian yang termasuk dalam kategori rendah terdapat 22 mahasiswa atau 4,7\%, untuk indeks kepuasan mahasiswa pada dimensi tangibles yang termasuk dalam kategori tinggi terdapat I35 mahasiswa atau 28.9\%, kemudian yang termasuk dalam kategori sedang terdapat 289 mahasiswa atau 61,9\%, kemudian yang termasuk dalam kategori rendah terdapat 43 mahasiswa atau 9,2\%, untuk indeks kepuasan mahasiswa pada dimensi empathyyang termasuk dalam kategori tinggi terdapat 289 mahasiswa atau 6I,9\%, kemudian yang termasuk dalam kategori sedang terdapat I6I mahasiswa atau 34,5\%, kemudian yang termasuk dalam kategori rendah terdapat I7 mahasiswa atau 3,6\%, dan untuk indeks kepuasan mahasiswa pada dimensi reliabillty, yang termasuk dalam kategori tinggi terdapat I53 mahasiswa atau 32,8\%, kemudian yang termasuk dalam kategori sedang terdapat 26I mahasiswa atau 55,9\%, kemudian yang termasuk dalam kategori rendah terdapat 53 mahasiswa atau II,3\%

Berikutnya gambaran indeks kepuasan mahasiswa pada aspek mediauntuk dimensi responsivness, yang termasuk dalam kategori tinggi terdapat 167 mahasiswa atau 35,8\%, kemudian yang termasuk dalam kategori sedang terdapat 230 mahasiswa atau 49,3\%, kemudian yang termasuk dalam kategori rendah terdapat 70 mahasiswa atau 15,0\%, untuk indeks kepuasan mahasiswa pada dimensi assurance yang termasuk dalam kategori tinggi terdapat 196 mahasiswa atau 42,0\%, kemudian yang termasuk dalam kategori sedang terdapat 232 mahasiswa atau 49,7\%, kemudian yang termasuk dalam kategori rendah terdapat 39 mahasiswa atau $8.4 \%$, untuk indeks kepuasan mahasiswa pada dimensi tangiblesyang termasuk dalam kategori tinggi terdapat I 40 mahasiswa atau 30,0\%, kemudian yang termasuk dalam kategori sedang terdapat 284 mahasiswa atau $60,8 \%$, kemudian yang termasuk dalam kategori rendah terdapat 43 mahasiswa atau $9,2 \%$, untuk indeks kepuasan mahasiswa pada dimensi empathy yang termasuk dalam kategori tinggi terdapat 276 mahasiswa atau $59,1 \%$, kemudian yang termasuk dalam kategori sedang terdapat 166 mahasiswa atau 35,5\%, kemudian yang termasuk dalam kategori rendah terdapat 25 mahasiswa atau 5,4\%, dan untuk indeks kepuasan mahasiswa pada dimensi reliabillty yang termasuk dalam kategori tinggi terdapat 206 mahasiswa atau 44,I\%, kemudian yang termasuk dalam kategori sedang terdapat 2I2 mahasiswa atau 45,4\%, kemudian yang termasuk dalam kategori rendah terdapat 49 mahasiswa atau 10,5\%. Hubungan antara kepuasan mahasiswa terhadap Faktor Sarana Prasarana, Perabotan, Peralatandan Media, dapat disimak pada table I matrik korelasi sederhana berikut ini.

Tabel I.Matrik Korelasi Sederhana Antara Kepuasan Mahasiswa terhadap Sarana Prasarana terhadap

Kepuasan Mahasiswa terhadap Aspek Perabotan, Kepuasan Mahasiswa terhadap Peralatan dan Kepuasan Mahasiswa terhadap Media

\begin{tabular}{|c|c|c|c|c|}
\hline $\mathrm{X}$ & I & 2 & 3 & $\mathrm{Y}$ \\
\hline I & 1,00 & $0,818^{\text {ind }}$ & $0,753^{\text {乘 }}$ & 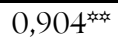 \\
\hline 2 & - & $\mathrm{I}, 00$ & $0,828^{\ldots}$ & $0,964^{\text {and }}$ \\
\hline 3 & - & - & $\mathrm{I}, 00$ & $0,920^{\text {nath }}$ \\
\hline $\mathrm{Y}$ & - & - & - & $\mathrm{I}, 00$ \\
\hline
\end{tabular}

Sangat signifikan $\mathrm{p}<0,01$

*Signifikan $\mathrm{p}<0,05$

Dari tabel I diketahui kepuasan mahasiswa pada aspek perabotan (XI) dan kepuasan mahasiswa terhadap aspek peralatan (X2) memiliki korelasi sebesar 0,8I8; p<0,0I. Kepuasan mahasiswa terhadap aspek perabotan (XI) dan kepuasan mahasiswa terhadap aspek media (X3) memiliki korelasi sebesar 0,753; p<0,0I. Kepuasan mahasiswa terhadap aspek perabotan (XI) dan kepuasan mahaisswa terhadap sarana dan prasarana 
(Y) memiliki korelasi sebesar 0,904; $\mathrm{p}<0$,0I.Kepuasan mahasiswa terhadap aspek peralatan (X2) dan kepuasan mahasiswa terhadap aspek media (X3) memiliki korelasi sebesar 0,828; p<0,0I. Kepuasan mahasiswa terhadap aspek peralatan (X2) terhadap sarana dan prasarana (Y) memiliki korelasi sebesar 0,964; dengan $\mathrm{p}<0,0 \mathrm{I}$. Kepuasan mahasiswa terhadap aspek media (X3) dan kepuasan mahasiswa terhadap sarana dan prasarana $(Y)$ memiliki korelasi 0,920; dengan $\mathrm{p}<0$,0I.Diantara 3 indikator dalam sarana prasarana kuliah jika dipilih sebagai prediktor, maka indikator "Kepuasan mahasiswa terhadap aspek peralatan (X3)" merupakan prediktor yang terbaik di antara indikator yang lain, karena memiliki korelasi yang tertinggi ( 0,964). Setelah dilakukan pengendalian pengaruh ubahan lain di antara prediktor-prediktor diperoleh koefisien korelasi secara parsial sebagaimana dapat disimak pada table 2 berikut.

Tabel 2. Matrik korelasi parsial kepuasan mahasiswa aspek perabotan $\left(\mathrm{X}_{\mathrm{I}}\right)$, kepuasan mahasiswa aspek peralatan $\left(\mathrm{X}_{2}\right)$, kepuasan mahasiswa aspek perabotan $\left(\mathrm{X}_{3}\right)$ terhadap kepuasan mahasiswa pada sarana prasarana

(Y)

\begin{tabular}{|c|c|c|c|}
\hline \multirow[t]{2}{*}{ Konstanta } & \multicolumn{3}{|c|}{ Kepuasan Mahasiswa } \\
\hline & ryxi & ryxz & ryx 3 \\
\hline $\mathrm{X}_{\mathrm{I}}$ & - & $0,818^{x}$ & $0,753^{3 x}$ \\
\hline $\mathrm{X}_{2}$ & $0,818^{2 x}$ & - & $0,828^{2 x}$ \\
\hline $\mathrm{X}_{3}$ & $0,753^{\text {站 }}$ & $0,828^{\text {柿 }}$ & - \\
\hline $\mathrm{X}_{1} \mathrm{X}_{2}$ & - & - & $\mathrm{I}, 00$ \\
\hline $\mathrm{X}_{\mathrm{I}} \mathrm{X}_{3}$ & - & $\mathrm{I}, \mathrm{OO}$ & - \\
\hline $\mathrm{X}_{2} \mathrm{X}_{3}$ & $\mathrm{I}, 00$ & - & - \\
\hline
\end{tabular}

${ }^{*}$ Sangat signifikan $\mathrm{p}<0,0 \mathrm{I}$

*Signifikan $\mathrm{p}<0,05$

Hubungan antara kepuasan mahasiswa pada aspek perabotan $\left(\mathrm{X}_{\mathrm{I}}\right)$ dan kepuasan mahasiswa pada sarana prasarana $(Y)$, pada korelasi jenjang nihil terdapat ry $=0,904$ dan sangat signifikan,setelah dikontrol dengan ubahan lainnya, pada korelasi jenjang pertama tidak terdapat perubahan arah korelasi akan tetapi terjadi penurunan saat dikontrol ubahan yang lain. Pada korelasi parsial jenjang kedua tetap tidak terdapat perubahan arah korelasi tetapi terdapat peningkatan pada saat dikendalikan oleh ubahan-ubahan $\mathrm{X}_{2} \mathrm{X}_{3}$. Korelasi murni yang di dapat ternyata positif dengan ry1-2.3 $=1,00$; dengan $\mathrm{p}>0,05$ sehingga nampak adanya kecendrungan bahwa kepuasan mahasiswa pada aspek perabotan $\left(\mathrm{X}_{\mathrm{I}}\right)$ memiliki hubungan yang sangat tinggi terhadap kepuasan mahasiswa pada sarana prasarana $(\mathrm{Y})$.

Hubungan antara kepuasan mahasiswa aspek peralatan $\left(\mathrm{X}_{2}\right)$ dan kepuasan mahasiswa pada sarana prasarana $(Y)$, korelasi jenjang nihil terdapat ryz $=0,964$ dan sangat signifikan. Setelah dikontrol dengan ubahan lainnya, pada korelasi jenjang pertama tidak terdapat perubahan arah korelasi akan tetapi terjadi penurunan saat dikontrol ubahan yang lain. Pada korelasi parsial jenjang kedua tetap tidak terdapat perubahan arah korelasi tetapi terdapat peningkatan pada saat dikendalikan oleh ubahan-ubahan $\mathrm{X}_{\mathrm{I}} \mathrm{X}_{2}$. Korelasi murni yang didapat ternyata positif dengan ry2-1.3 $=1,00$ tetapi tidak signifikan karena $\mathrm{p}>0,05$ sehingga nampak adanya kecendrungan bahwa kepuasan mahasiswa aspek peralatan $\left(\mathrm{X}_{2}\right)$ memiliki hubungan yang sangat tinggi terhadap kepuasan mahasiswa pada sarana prasarana (Y) meskipun tidak signifikan.

Hubungan antara kepuasan mahasiswa aspek media $\left(\mathrm{X}_{3}\right)$ dan kepuasan mahasiswa pada sarana prasarana $(Y)$, korelasi jenjang nihil terdapat ryz $=0,920$ dan sangat signifikan. Setelah dikontrol dengan ubahan lainnya, pada korelasi jenjang pertama tidak terdapat perubahan arah korelasi akan tetapi terjadi penurunan saat dikontrol ubahan lain. Pada korelasi parsial jenjang kedua tetap tidak terdapat perubahan arah korelasi tetapi terdapat peningkatan pada saat dikendalikan oleh ubahan-ubahan $\mathrm{X}_{\mathrm{I}} \mathrm{X}_{3}$. Korelasi murni yang di dapat ternyata positif dengan ry3-1.2 $=1,000$ tetapi tidak signifikan karena $\mathrm{p}>0,05$ sehingga nampak adanya kecenderungan bahwa kepuasan mahasiswa aspek media $\left(\mathrm{X}_{3}\right)$ memiliki hubungan yang sangat tinggi terhadap kepuasan mahasiswa terhadap sarana prasarana (Y) meskipun tidak signifikan. Diantara 3 indikator dalam 
sarana prasarana kuliah yang paling besar memiliki pengaruh kepuasan mahasiswa terhadap sarana prasarana untuk kepuasan mahasiswa pada aspek peralatan yaitu 0,964, akan tetapi semua indikator memiliki pengaruh yang sangat sempurna.

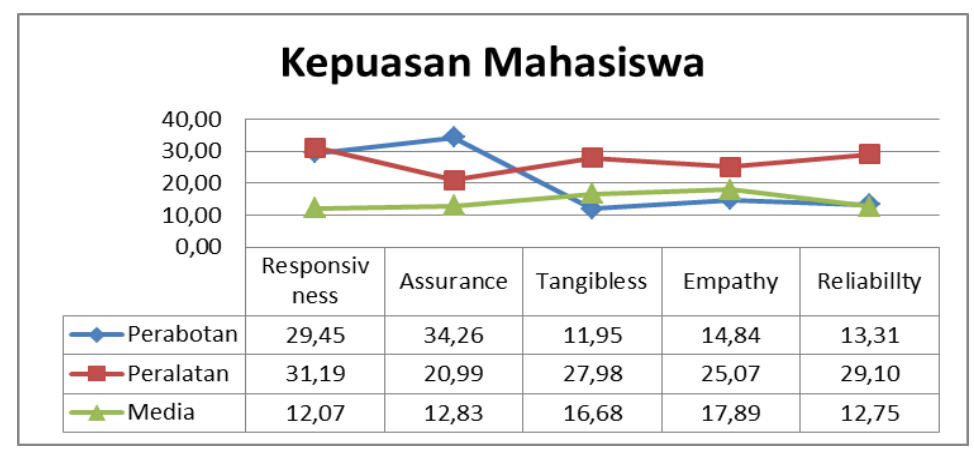

Gambar I. Profil Dimensi Tingkat Kepuasan MahasiswaTerhadap Pemanfaatan Sarana-Prasarana Kuliah di FKIP ULM

Berdasarkan hasil analisis deskriftif untuk tingkat kepuasan mahasiswa dilihat dari aspek perabotan yang paling tinggi adalah dari assurance dengan rata-rata 34,26, sedangkan yang paling rendah pada tangibles dengan rata-rata II,95. Pada aspek perbotan dimensi assurance memiliki rata-rata yang tinggi karena mahasiswa merasa nyaman dalam memakai kursi kuliah dan pada aspek perabotan dimensi tangibles memiliki rata-rata rendah karena mahasiswa merasa ada ruang kuliah yang memiliki kursi yang kurang atau tidak sebanding dengan jumlah mahasiswanya. Terkadang untuk tiap mata kuliah berbeda-beda jumlah mahasiswanya, hal ini dapat dilihat dari pengisian angket banyaknya mahasiswa mengisi kurang puas dan juga sebagaian hasil wawancara kepada mahaisswa.

Tingkat kepuasan mahasiswa dilihat dari aspek peralatan yang paling tinggi adalah dari responsiveness dengan rata-rata 3I,I9, sedangkan yang paling rendah pada assurance dengan rata-rata 20,99. Pada aspek peralatan dimensi responsiveness memiliki rata-rata yang tinggi karena papan tulis dan LCD sudah cukup tersedia untuk setiap ruang kuliah dan pada aspek peralatan dimensi assurance memiliki rata-rata rendah karena mahasiswa merasa masih kurang tersedianya kipas angin atau pendingin ruangan.

Tingkat kepuasan mahasiswa dilihat dari aspek media yang paling tinggi adalah dari empathy dengan ratarata 17,89, sedangkan yang paling rendah pada responsiveness dengan rata-rata 12,07. Pada aspek media dimensi empathy memiliki rata-rata yang tinggi karena tingkat kepedulian dan rasa bertanggung jawab mahasiswa terhadap sarana prasarana cukup tinggi, seperti dalam peminjaman dan pengembalian pengeras suara dan pada aspek media dimensi responsiveness memiliki rata-rata rendah karena mahasiswa merasa masih kurang puas dengan ketersediaan fasilitaswi-fi yang tidak sama dengan jumlah ruangan kuliah, sehingga mempersulit mahasiswa bila dalam proses pembelajaran menggunakan internet. Selanjutnya pada gambar berikut dapat diamati paradigma hubungan dimensi kepuasan mahasiswa: responsiveness, assurance, tangibles, empathy dan reliabillty terhadap pemanfaatan sarana dan prasarana di FKIP ULM. 


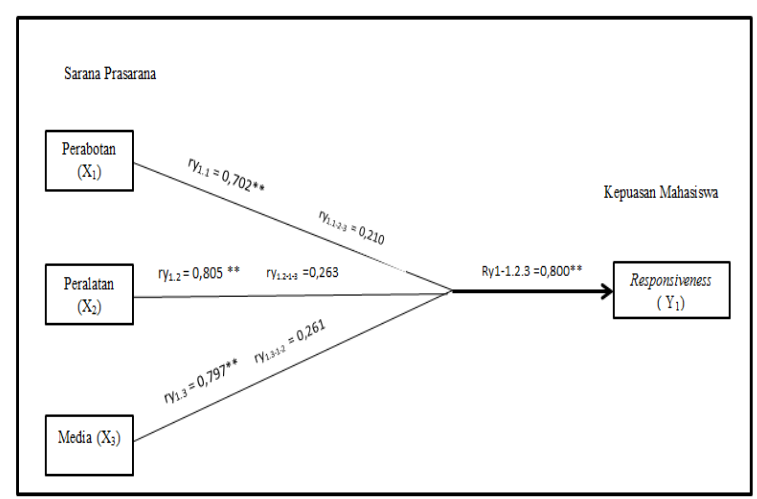

Gambar 4.2 paradigma penelitian dimensi reesponsiveness

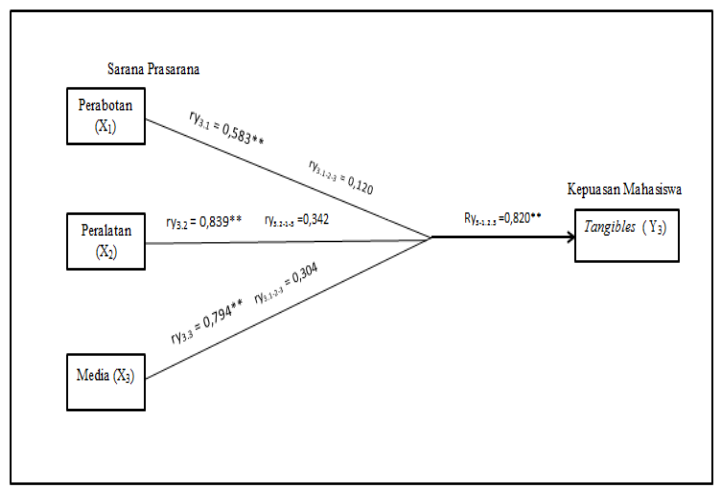

Gambar 4.3 paradgn apenelititin dim ensitangiblest

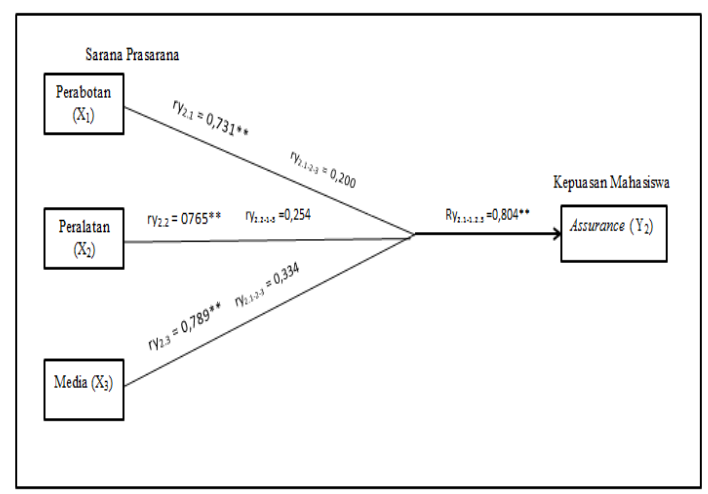

Gambar4.2paradigna penenelitian dimensiassuruconce

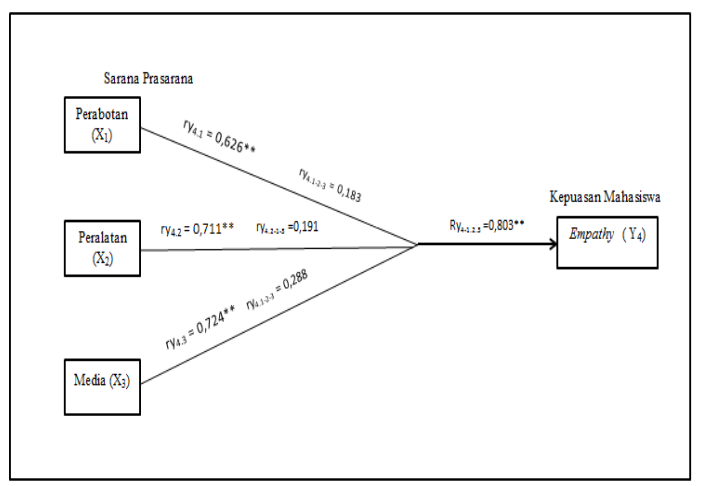

Gambar 4.4 paradign apenelitinanempath

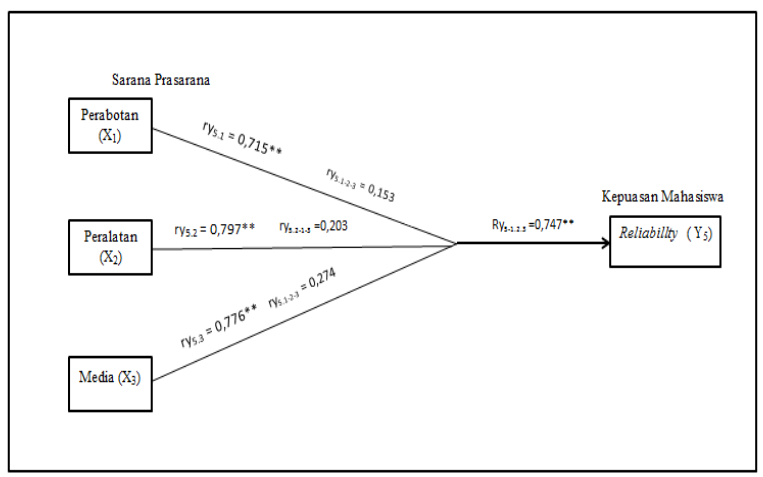

Gambar4.5 paradigna penelitian reliabillty

Gambar 2:Paradigma hubungandimensikepuasanterhadappemanfaatansarana-prasarana: responsiveness, assurance, tangibles, empathy dan reliabillty.

Berdasarkan gambar diatas diketahui bahwa pada dimensi responsiveness tingkat kepuasan dipengaruhi oleh aspek perabotan, peralatan dan media secara bersama dengan Ry 11.12.13 $=0,800 p<0,0$ I dengan korelasi parsial masing-masing aspek dengan aspek perabotan ryı $=0,210 p<0,05 ;$ ry2 $=0,263 p<0,05 ;$ ry3 $=0,26 \mathrm{I}$ $\mathrm{p}<0,05$, untuk dimensi assurance Ry21.22.23 $=0,804 \mathrm{p}<0,0$ I dengan korelasi parsial masing-masing aspek perabotan ryı $=0,200 \mathrm{p}<0,05$; aspek peralatan ryz $=0,254 \mathrm{p}<0,05 ;$ dan aspek mediary $=0,334 \mathrm{p}<0,05$, untuk dimensi tangibles dengan Ry21.22.23 $=0,820 \mathrm{p}<0$,0I dengan korelasi parsial masing-masing aspek perabotan ryi $=0,120 \mathrm{p}<0,05$; aspek peralatan ryz $=0,342 \mathrm{p}<0,05 ;$ dan aspek media ry $=0,304 \mathrm{p}<0,05$, untuk dimensi empathy dengan Ry41.42.43 $=0,803 \mathrm{p}<0$,0I dengan korelasi parsial masing-masing aspek perabotan ryI $=0,183 \mathrm{p}<0,05$; aspek peralatan ry2 $=0,191 \mathrm{p}<0,05$; dan aspek media ry3 $=0,288 \mathrm{p}<0,05$, dan untuk dimensi reliabillty tingkat kepuasan dipengaruhi oleh aspek perabotan, peralatan dan media secara 
bersama dengan Ry51.52.53 $=0,747 \mathrm{p}<0,0 \mathrm{I}$ dengan korelasi parsial masing-masing aspek perabotan ryI $=0, \mathrm{I} 53$ $\mathrm{p}<0,05$; aspek peralatan ry2 $=0,203 \mathrm{p}<0,05$; dan aspek mediary $3=0,274 \mathrm{p}<0,05$. Berdasakan hasil paradigma pada gambar diketahui untuk tingkat kepuasan dipengaruhi aspek perabotan, peralatan dan media paling tinggi berada pada tangibles dengan Ry31.32.33 $=0,820 \mathrm{p}<0,0 \mathrm{I}$ dan untuk pengauh paling rendah berada pada tangibles dengan Rys..52.53 $=0,747$ p <0,0I.

\section{Penutup}

Analisis deskriftif untuk tingkat kepuasan mahasiswa dilihat dari aspek perabotan yang paling tinggi adalah dari assurance dengan rata-rata 34,26, sedangkan yang paling rendah pada tangibles dengan rata-rata II,95. Tingkat kepuasan mahasiswa dilihat dari aspek peralatan yang paling tinggi adalah dari responsiveness dengan rata-rata 3I,I9, sedangkan yang paling rendah pada assurance dengan rata-rata 20,99. Tingkat kepuasan mahasiswa dilihat dari aspek media yang paling tinggi adalah dari empathy dengan rata-rata 17,89 , sedangkan yang paling rendah pada responsiveness dengan rata-rata 12,07 . Hasil paradigma menunjukkan pada dimensi responsiveness tingkat kepuasan dipengaruhi oleh aspek perabotan, peralatan, dan media secara bersama dengan Ry11.12.13 $=0,800 \mathrm{p}<0,0 \mathrm{I}$, untuk dimensi assurance dengan Ry21.22.23 $=0,804 \mathrm{p}<0,0 \mathrm{I}$, untuk dimensi tangibles dengan Ry31.32.33 $=0,820 \mathrm{p}<0,01$, untuk dimensi empathy dengan Ry41.42.43 $=0,803 \mathrm{p}<0,0 \mathrm{I}$ dan untuk dimensi reliabillty dengan Ry51.52.53 $=0,747 \mathrm{p}<0,0$ I. Diketahui bahwa untuk sarana prasarana yang memiliki pengauh paling tinggi pada kepuasan mahasiswa berada pada tangibles dengan Ryз1.32.33 $=0,820$ $\mathrm{p}<0$,OI untuk aspek peralatan, sedangkan sarana prasarana yang memiliki pengauh paling rendah. pada kepuasan mahasiswa berada pada reliabillty dengan $\operatorname{Rysi.52.53}=0,747 \mathrm{p}<0,0$ I untuk aspek media.Penelitian ini diharapkan sebagai bahan pertimbangan dalam penyedian sarana dan prasaran kuliah yang ada di FKIP ULM dan juga dalam melakukan perbaikan-perbaikan yang dirasa masih kurang dalam perbaikan baik itu dari perabotan, peralatan dan media digunakan untuk membantu saat pembelajaran di ruang kuliah dan agar para mahasiswa sebagai pengguna sarana dan prasaran kuliah di FKIP ULM agar menjaga sarana prasarana yang telah disediakan oleh FKIP dan menghormati segala kebijakan yang telah dibuat secara dewasa dan bijaksana.

\section{Daftar Pustaka}

Apriyanti, D. A., \& Sunarti. (2017). Pengaruh Kualitas Pelayanan terhadap Kepuasan Konsumen. JurnalAdministrasi Bisnis, $5 \mathrm{I}$ (I), $3 \& 272$.

Bhakti, Y. B., \& Rahmawati, E. Y. (2017). Indeks Kepuasan Mahasiswa terhadap Pelayanan Program Studi Pendidikan Matematika. JurnalFormatif, 7 (3), 276.

Fauzan. A. (2018). Manajemen Sarana Dan Prasarana Pondok Pesantren Shuffah Hisbullah Natar Lampung Selatan. Jurnal Kajian Ilmu Pendidikan, 3 (I), 250.

Irawan. A. \& Komara, E. F. (2017) .Pengukuran Tingkat Kepuasan Masyarakat Terhadap Pelayanan Pemerintahan Kecamatan Katapang Kabupaten Bandung. Jurnal Inspirasi Bisnis dan Manajemen, I (2), I26.

Lestari. D. N., \& Yusmiono. B. A. (2018). Analisis Penggunaan Sarana Dan PrasaranaUntuk Menunjang Kegiatan Belajar MahasiswaDi Universitas PGRI Palembang Tahun Akademik 2016/2017. Jurnal Manajemen, Kepemimpinan, dan Supervisi Pendidikan, 3 (I), 4I.

Megasari. R. (2014). Peningkatan Pengelolaan Sarana Prasarana Pendidikan untuk Meningkatkan Kualitas Pembelajaran di SMPN 5 Bukit Tinggi. JurnalAdministrasi Pendidikan, 2 (I), 639.

Martasubrata. N. \& Suwatno (2016). Mutu layanan akademik sebagai determinan kepuasan mahasiswa. Jurnal Pendidikan Manajemen Perkantoran, I (I), I37.

Prastyawan. (2016). Manajemen Sarana Prasarana Pendidikan. Jurnal Studi Keislaman, 6 (I) , 44. 
Sari, M. K. (2015). Pengaruh Standarisasi Sarana dan Prasarana Pendidikan terhadap Hasil Belajar Siswa Kecamatan Sangasanga Kabupaten Kutai Kartanegara. Ejournal Ilmu Pemerintahan, 3 (3), 1398.

Sawitry, Henny. I. (2015). Pengaruh Sarana Dan Prasarana Pendidikan Terhadap Efektivitas Proses Belajar Mengajar Pada Mahasiswa SI Program Studi Ilmu Administrasi Negara Fakultas Ilmu Sosial Dan Politik Universitas Mulawarman. Jounal Administrasi Negara, 3(2), 581.

Yama, S. F., \& Setiyani, R. (2016). Pengaruh Pelatihan Guru, Kompetensi Guru dan Pemanfaatan Sarana Prasarana Terhadap Kesiapan Guru Prodi Bisnis Manajemen dalam Implementasi Kurikulum 2013. Economic Education Analysis Journal, 5 (I), 97. 